\title{
Metabolism of Lactobacillus sakei Chr82 in the Presence of Different Amounts of Fermentable Sugars
}

\author{
Federica Barbieri ${ }^{1}$, Luca Laghi ${ }^{1,2}{ }^{-}$, Fausto Gardini ${ }^{1,2}$, Chiara Montanari ${ }^{2, *}$ and \\ Giulia Tabanelli 2,3 (D) \\ 1 Department of Agricultural and Food Sciences, University of Bologna, 47521 Cesena, Italy; \\ federica.barbieri16@unibo.it (F.B.); 1.laghi@unibo.it (L.L.); fausto.gardini@unibo.it (F.G.) \\ 2 Interdepartmental Center for Industrial Agri-Food Research, University of Bologna, 47521 Cesena, Italy; \\ giulia.tabanelli2@unibo.it \\ 3 Department of Agricultural and Food Sciences, University of Bologna, 40127 Bologna, Italy \\ * Correspondence: chiara.montanari8@unibo.it; Tel.: +39-34-0649-7745
}

Received: 26 March 2020; Accepted: 27 May 2020; Published: 2 June 2020

Abstract: Lactobacillus sakei is widely used as a starter culture in fermented sausages since it is well adapted to meat environments and able to maintain high viability thanks to secondary pathways activated when hexoses are depleted (i.e., metabolism of pentoses and amino acids). In this study, a commercial strain of $L$. sakei was inoculated in a defined medium with ribose or glucose as the carbon source, at optimal or reduced concentrations, to evaluate its different physiological and metabolic responses in relation to different growth conditions. The results obtained with different approaches (HPLC, ${ }^{1} \mathrm{H}-\mathrm{NMR}$, flow cytometry) evidenced different growth performances, amino acid consumptions and physiological states of cells in relation to the carbon source as an active response to harsh conditions. As expected, higher concentrations of sugars induced higher growth performances and the accumulation of organic acids. The low sugars amount induced the presence of dead cells, while injured cells increased with ribose. Arginine was the main amino acid depleted, especially in the presence of higher ribose, and resulted in the production of ornithine. Moreover, the ${ }^{1} \mathrm{H}-\mathrm{NMR}$ analysis evidenced a higher consumption of serine at the optimal sugars concentration (pyruvate production). This information can be helpful to optimize the use of these species in the industrial production of fermented sausages.

Keywords: Lactobacillus sakei; sugar metabolism; amino acid metabolism; ${ }^{1} \mathrm{H}-\mathrm{NMR}$; flow cytometry

\section{Introduction}

Lactobacillus sakei is a species with a high level of adaptation for meat environments in which it can rapidly grow and efficiently compete with other species present as components of the microbial communities of this raw material. Due to this aptitude, selected strains of this species are widely used as starter cultures in meat fermentation for dry sausages production [1]. The technological and safety advantage of the use of this species as a starter culture consists in its ability to inhibit pathogenic as well as spoilage microorganisms, to grow at a low temperature and to colonize the habitat during all of the ripening period, competing with undesired species [2]. This latter aspect, essential for guaranteeing the quality of fermented sausages throughout all the steps of production and commercialization, depends on its ability to efficiently produce metabolic energy even when the hexoses, which are fermented through the homofermentative pathway, are completely depleted. In fact, this species can also ferment pentoses contained in the nucleosides via the phosphoketolase pathway, as demonstrated by McLeod et al. [3] and Rimaux et al. [4]. 
Moreover, the arginine deiminase (ADI) pathway is active in L. sakei, even if with different efficiency. This pathway is an important additional energy source giving a competitive advantage in matrices with a low fermentable sugar concentration but high arginine content, such as meat $[5,6]$.

The mean genotype size of $L$. sakei is relatively small (approximately $2020 \mathrm{~kb}$ ) and reflects this specialization, even if a great variation in genome dimension is observed within the species (about 25\%) [7]. The adaptation to grow in proteinaceous matrices (meat and fish) explains the absence of genes responsible for amino acid anabolism, in particular, transaminases: L. sakei strains are auxotrophic for all the amino acids, except for aspartate and glutamate [8]. Nevertheless, the metabolisms of some of these compounds are crucial for explaining the success of this species in the colonization of fermented meat.

In addition to the use of arginine for energy supply, other amino acids may be useful for the energetic strategies of this bacterium. Serine may be deaminated by L-serine dehydratase, yielding a surplus of pyruvate, and relevant uptakes of this molecule in defined media by $L$. sakei have been observed [5,6]. Threonine [5] and cysteine [6] were depleted in remarkable amounts (higher than those required by the generation of the intracellular amino acid pool) by this species under defined conditions. The presence of a gene coding for L-threonine dehydrogenase active in some L. sakei strains has been described: this protein catalyzes the conversion to glycine via 2-amino-3-ketobutyrate with a concomitant $\mathrm{NAD}^{+}$reduction to NADH [5].

Survival and growth in environments poor in fermentable sugars have been also explained by an efficient pyruvate metabolism carried out for generating further ATP and gaining reducing power (regeneration of $\mathrm{NAD}^{+}$). The pyruvate formate lyase (PFL) pathway leads to the possible accumulation of by-products such as formate, acetate and ethanol in anaerobic or reducing conditions, while in an aerobic condition, $\mathrm{CO}_{2}$ and acetate may be produced through the pyruvate oxidase (POX) pathway and the pyruvate dehydrogenase complex (PDC). Enzymes involved in these pathways were found in L. sakei and their transcription was enhanced in the presence of pentoses as the fermentable substrate $[9,10]$.

The same authors also demonstrated that glucose availability can affect different parameters such as growth rate, fermentative pathway (i.e., shift from homolactic to mixed acid fermentation), amino acid consumption and gene expression, but no effect on cell viability (in terms of percentage of alive cells) was observed. They hypothesized that this condition of low glucose availability is for L. sakei analogous to the so-called "complete caloric restriction", that in eukaryotes, from single-celled yeast to humans, is a conserved mechanism that results in an expanded healthy life span in response to a reduction in energy intake [5].

A previous work was focused on the evaluation of the metabolic response of resting cells of six L. sakei strains in relation to the sugar presence (glucose or ribose) [6]. Cells in the stationary phase were inoculated at high concentrations (about $9 \log \mathrm{CFU} / \mathrm{mL}$ ) in a defined medium (DM) and incubated for $24 \mathrm{~h}$ to assess the consumption of sugars and amino acids and the resulting accumulation of organic acids and other metabolites.

Based on the obtained results, the strain L. sakei Chr82 (used as a commercial starter culture in fermented sausage production) was chosen for the present work in order to study its growth, survival and metabolic response when inoculated at about $7 \log \mathrm{CFU} / \mathrm{mL}$ in different DMs containing glucose or ribose at two initial concentrations ( $25 \mathrm{mM}$ or $2.5 \mathrm{mM})$, to simulate an optimal or limited growth condition.

With the aim to better investigate the physiological response of this strain, different analytical approaches were used. In particular, cell cultivability was tested by plate count while flow cytometry was used to assess cell membrane permeability and depolarization as well as cell viability. Moreover, organic acid accumulation and amino acid variation were quantified by HPLC and the results were compared and discussed with metabolome analyses, performed by ${ }^{1} \mathrm{H}-\mathrm{NMR}$. This latter aspect, that is the complete set of small metabolites consumed or produced [11], was done on the assumption that the metabolome would be the best representation of the microorganism phenotype, being downstream 
of the genome, transcriptome, and proteome. The analytical platform selected for this purpose was ${ }^{1} \mathrm{H}-\mathrm{NMR}$, whose high reproducibility was expected to counterbalance the low sensitivity [12]. Moreover, this technique does not require derivatization or molecular separation and allows the untargeted, simultaneous detection of molecules pertaining to a broad range of chemical classes.

\section{Materials and Methods}

\subsection{Microorganism Used}

The commercial strain Lactobacillus sakei Chr82, supplied by the company Chr. Hansen (Parma, Italy), used as a starter culture in the production of fermented cured meats, was used.

\subsection{Growth Media}

L. sakei Chr82 was pre-grown in MRS broth prepared according to Oxoid formulation (peptone $10 \mathrm{~g} / \mathrm{L}$, lab-lemco powder $8 \mathrm{~g} / \mathrm{L}$, yeast extract $4 \mathrm{~g} / \mathrm{L}$, Tween $801 \mathrm{~mL} / \mathrm{L}$, dipotassium hydrogen phosphate $2 \mathrm{~g} / \mathrm{L}$, sodium acetate $3 \mathrm{H}_{2} \mathrm{O} 5 \mathrm{~g} / \mathrm{L}$, triammonium citrate $2 \mathrm{~g} / \mathrm{L}$, magnesium sulphate $7 \mathrm{H}_{2} \mathrm{O} 0.2 \mathrm{~g} / \mathrm{L}$, manganese sulphate $4 \mathrm{H}_{2} \mathrm{O} 0.05 \mathrm{~g} / \mathrm{L}$ ) and with the addition of two different sugars: in one case, $4.5 \mathrm{~g} / \mathrm{L}$ of glucose, while in the other, $3.75 \mathrm{~g} / \mathrm{L}$ of ribose were added. In the medium with ribose, according to the observation by McLeod et al. [3], a small amount of glucose was also added $(0.2 \mathrm{~g} / \mathrm{L})$ in order to stimulate the growth of the microorganism in the initial phase.

The cells grown overnight under statically microaerophilic conditions at $30^{\circ} \mathrm{C}$ in modified MRS were collected by centrifugation at 10,000 rpm for $10 \mathrm{~min}$ and suspended in a defined medium (DM), containing macro components, vitamins, nucleotides and amino acids. This DM, whose composition is reported in Table 1, is a modification of the medium proposed by Lauret et al. [13] for the growth of L. sakei. Amino acids were added at $0.2 \mathrm{~g} / \mathrm{L}$. The consequent $\mathrm{mM}$ concentration was as follows: alanine (ala) 2.24, arginine (arg) 1.15, asparagine (asg) 1.52, aspartic acid (asp) 1.50, cysteine (cys) 1.65, glutamic acid (glu), glutamine (glm) 1.36, glycine (gly) 2.66, histidine (his) 1.29, isoleucine (ile) 1.52 , leucine (leu) 1.52 , lysine (lys) 1.37, methionine (met) 1.34, phenylalanine (phe) 1.21, proline (pro) 1.74, serine (ser) 1.90 , threonine (thr) 1.68, tryptophan (try) 0.98 , tyrosine (tyr) 1.10, valine (val) 1.71.

Table 1. Chemically defined medium (DM) composition.

\begin{tabular}{cc}
\hline Compound & Concentration $(\mathrm{g} / \mathrm{L})$ \\
\hline Macro components & 2.0 \\
Sodium acetate & 1.75 \\
$\mathrm{~K}_{2} \mathrm{HPO}_{4}$ & 0.012 \\
$\mathrm{MnSO}_{4} 4 \mathrm{H}_{2} \mathrm{O}$ & 0.2 \\
$\mathrm{MgSO}_{4} 7 \mathrm{H}_{2} \mathrm{O}$ & $1 \mathrm{~mL}$ \\
Tween 80 & \\
Vitamins & 0.0011 \\
Thiamine $\mathrm{HCl}$ & 0.0002 \\
Folic acid & 0.001 \\
Riboflavin & 0.001 \\
Calcium pantothenate & 0.001 \\
Nicotinic acid & 0.0005 \\
Pyridoxal-5-phosphate & 0.0004 \\
p-amino benzoic acid & \\
Nucleotides & 0.005 \\
Adenine & 0.01 \\
Guanine & 0.01 \\
Uracil &
\end{tabular}


The cells of L. sakei grown in the presence of glucose were suspended in DM with $2.5 \mathrm{mM}$ of glucose and subsequently inoculated in the two DM added with glucose $2.5 \mathrm{mM}(2.5 \mathrm{G})$ or $25 \mathrm{mM}$ ( $25 \mathrm{G})$, at a cell concentration of about $7 \log \mathrm{CFU} / \mathrm{mL}$. The same procedure was applied for $L$. sakei Chr82 cells grown with ribose, but in this case the cells were suspended in DM with ribose $2.5 \mathrm{mM}$ and then inoculated (cell load $7 \log \mathrm{CFU} / \mathrm{mL}$ ) in the two DM added with ribose $2.5 \mathrm{mM}(2.5 \mathrm{R})$ or $25 \mathrm{mM}(25 \mathrm{R})$. In the samples containing ribose, a small amount of glucose $(0.1 \mathrm{mM})$ was added in order to provide the energy needed to activate the ribose metabolism related genes, as indicated by McLeod et al. [3]. The medium was sterilized by filtration at $0.22 \mu \mathrm{m}$ (Sartorius Lab Instruments GmbH \& Co. KG, Göttingen, Germany). The initial $\mathrm{pH}$ of the medium was $6.50 \pm 0.02$.

Inoculated samples were incubated at $30^{\circ} \mathrm{C}$ and monitored at different times.

\subsection{Growth Modeling and $p H$ Measurement}

Growth performances were analyzed by measuring the increase in the optical density at $600 \mathrm{~nm}$ $\left(\mathrm{OD}_{600}\right)$ using the UV-VIS spectrophotometer $6705 \mathrm{UV}$ - Vis (Jenway, Stone, UK). Before each detection, a calibration of the instrument was performed with the blank (non-inoculated medium) of the respective sample.

The results of the optical density were modelled using the STATISTICA program (Statsoft Italia, Vigonza, Italy) through the Gompertz equation [14]:

$$
y=k+A \cdot e^{-e^{\left[\left(\frac{\mu_{\max } \cdot e}{A}\right) \cdot(\lambda-t)+1\right]}}
$$

where $y$ is the $\mathrm{OD}_{600}$ at time $t, A$ represents the maximum $\mathrm{OD}_{600}$ value reached, $\mu_{\text {max }}$ is the maximum $\mathrm{OD}_{600}$ increase rate in the exponential phase and $\lambda$ is the lag time.

The $\mathrm{pH}$ meter Basic 20 (Crison, Modena, Italy) was used for the sample $\mathrm{pH}$ measurement in order to monitor the acidification activity in the different conditions.

\subsection{Microbiological Analysis}

The microbiological counts of L. sakei Chr82 were carried out by plate counting in MRS agar (Oxoid, Basingstoke, United Kingdom) incubated aerobically for $48 \mathrm{~h}$ at $30^{\circ} \mathrm{C}$.

\subsection{Organic Acids Content}

The quantification of organic acids was performed using a HPLC instrument (PU-2089 Intelligent HPLC quaternary pump, UV-VIS multiwavelength detector UV 2070 Plus; Jasco Corp., Tokyo, Japan) equipped with a manual Rheodyne injector with a $20 \mu \mathrm{L}$ loop (Rheodyne, Rohnert Park, CA, USA) and a Bio-Rad Aminex HPX-87H column with a size of $300 \times 7.8 \mathrm{~mm}$ (Bio-Rad Laboratories, Hertfordshire, UK).

The analysis was performed in isocratic conditions at $65{ }^{\circ} \mathrm{C}$ with a rate flow of $0.6 \mathrm{~mL} / \mathrm{min}$ of mobile phase $\mathrm{H}_{2} \mathrm{SO}_{4} 0.005 \mathrm{M}$. The UV detector was set at $210 \mathrm{~nm}$. Chromatographic peaks were identified by comparing retention times with those of standards (Sigma-Aldrich, St. Louis, MO, USA) and quantification was carried out by using the external standard method.

\subsection{Quantification of Amino Acids}

To evaluate the variation in the amino acid concentration, samples were analyzed by HPLC (PU-1580 Intelligent HPLC, Intelligent Fluorescence Detector FP-1520 and Intelligent Sampler AS-2055 Plus, with $10 \mu \mathrm{L}$ loop; Jasco Corp., Tokyo, Japan), after a derivatization using an AccQ-Fluor Reagent kit (Waters Corp., Milford, MA, USA) according to the method described by Montanari et al. [6].

The separation of amino acids was performed using an AccQ-Tag TM column $(3.9 \times 150 \mathrm{~mm}$; Waters Corp.) at $30^{\circ} \mathrm{C}$ using mobile phase A (100 mL of AccQ-Tag Eluent (Waters Corp., Milford, MA, USA), diluted 1:10 with $\mathrm{H}_{2} \mathrm{O}$ for chromatography (Sigma-Aldrich, St. Louis, MO, USA) and mobile 
phase B (60\% acetonitrile and $40 \% \mathrm{H}_{2} \mathrm{O}$ for chromatography (Sigma-Aldrich, St. Louis, MO, USA)) at a flow rate of $1 \mathrm{~mL} / \mathrm{min}$. The fluorescent detector was set at an excitation wavelength of $250 \mathrm{~nm}$ and emission wavelength of $395 \mathrm{~nm}$. Under the adopted conditions, good separation of the amino acids was obtained with the exception of the couples histidine + glutamine and serine + asparagine, which coeluted in unique peaks. Tryptophan was not detectable with this protocol.

\subsection{Flow Cytometric Analysis}

Flow cytometry (FCM) was used to monitor the physiological state of L. sakei Chr82 cells in each sample. Cell suspensions were analyzed with the flow cytometer Accuri C6 (BD Biosciences, Milan, Italy), using setting parameters, emission filters and thresholds according to Arioli et al. [15].

Before the analysis, where necessary, the samples were diluted in the corresponding DM up to a concentration of $7 \log \mathrm{CFU} / \mathrm{mL}$, the optimal cell density for a correct sample staining by fluorochromes.

The cells were stained with SYBR-Green I (1X), propidium iodide (PI) $7.5 \mu \mathrm{M}$ and DiBAC 4 (3) (Bis-(1,3-Dibutylbarbituric Acid) Trimethine Oxonol) $3.0 \mu \mathrm{M}$ as reported by Tabanelli et al. [16]. The data obtained were analyzed using the BD ACCURITM C6 software version 1.0 (BD Biosciences, Milan, Italy). Before analysis, each aliquot was kept at $37^{\circ} \mathrm{C}$ for $15 \mathrm{~min}$ in order to let the dye react with the cells.

\subsection{Untargeted Metabolomics Analysis by ${ }^{1} H-N M R$}

For the metabolomics investigation by ${ }^{1} \mathrm{H}-\mathrm{NMR}$, an analysis solution was created, with 3-(trimethylsilyl)-propionic-2,2,3,3-d4 acid sodium salt (TSP) $10 \mathrm{mM}$ in $\mathrm{D}_{2} \mathrm{O}$, set at $\mathrm{pH} 7.00 \pm 0.02$ by means of $1 \mathrm{M}$ phosphate buffer. The solution contained also $10 \mu \mathrm{L}$ of $\mathrm{NaN}_{3} 2 \mathrm{mM}$, to avoid microbial proliferation, while TSP was employed as the ${ }^{1} \mathrm{H}$ NMR chemical-shift reference, as suggested by Zhu et al. [17]. Growth medium samples were prepared for ${ }^{1} \mathrm{H}-\mathrm{NMR}$ by thawing and centrifuging $1 \mathrm{~mL}$ of each for $15 \mathrm{~min}$ at $18,630 \mathrm{~g}$ and $4^{\circ} \mathrm{C}$. An amount of $700 \mu \mathrm{L}$ of supernatant was added to $200 \mu \mathrm{L}$ of the ${ }^{1} \mathrm{H}$ NMR analysis solution. Finally, each of the so-obtained samples was centrifuged again at the above conditions right before analysis.

${ }^{1} \mathrm{H}-\mathrm{NMR}$ spectra were recorded at $298 \mathrm{~K}$ with an AVANCE III spectrometer (Bruker, Milan, Italy), operating at a frequency of $600.13 \mathrm{MHz}$, equipped with the software Topspin 3.5. Following the procedure described by Laghi et al. [12], the HOD residual signal was suppressed by applying the first increment of the nuclear overhauser effect spectroscopy (NOESY) pulse sequence and a spoil gradient. This was done by employing the NOESYGPPR1D sequence, part of the standard pulse sequence library. Each spectrum was acquired by summing up 256 transients using $32 \mathrm{~K}$ data points over a $7184 \mathrm{~Hz}$ spectral window, with an acquisition time of $2.28 \mathrm{~s}$. The spectra were phase- and baseline-adjusted in Tospin, that was employed also for the calculation of the signal-to-noise ratio. Spectra were elaborated with the R package (R Core Team, 2018, Vienna, Austria) as reported by Zhu et al. [17]. Molecules identification was performed by comparing their signals with those of pure compounds by the Chenomx software ver. 8.3 (Chenomx Inc., Edmonton, AB, Canada) with the Chenomx (ver. 10) and HMDB (release 2) libraries.

\section{Results and Discussion}

\subsection{Determination of Growth Curves and Microbiological Analysis}

The DM containing the two different sugars (glucose and ribose) at the two different concentrations ( 2.5 and $25 \mathrm{mM}$ ) were inoculated with approximately $7 \log \mathrm{CFU} / \mathrm{mL}$ of L. sakei Chr82. The experimental data of the growth dynamics monitored by measuring the $\mathrm{OD}_{600}$ were modelled with the Gompertz equation [14] and are reported in Supplementary Materials Figure S1. The growth parameters obtained, together with the cell concentrations after 24 and $48 \mathrm{~h}$ of incubation, are summarized in Table 2. The amount of sugars influenced the maximum $\mathrm{OD}_{600}$, which reached values of 0.264 and 0.282 in the presence of glucose and ribose at $2.5 \mathrm{mM}$, respectively, while, under the same conditions, the maximum 
$\mathrm{OD}_{600}$ predicted when the sugars were added at $25 \mathrm{mM}$ were 1.446 and 1.151 . The addition of ribose determined a slightly longer $\lambda$ time and lower $\mu_{\max }$. Regarding the cell concentrations after 24 and $48 \mathrm{~h}$ of growth, determined by plate counting, no significant differences were found after $24 \mathrm{~h}$ in the different media (Table 2). After $48 \mathrm{~h}$, cell loads showed a drastic decline ( 1 log unit or more) if compared with the counts at $24 \mathrm{~h}$ and the higher survival rate was observed in the sample containing $2.5 \mathrm{mM} \cdot \mathrm{R}$. The rapid beginning of the death phase in culture media for this species has already been observed [18] and it is in contrast with the long survival showed by L. sakei in stricter conditions as those characterizing fermented sausages during ripening.

Table 2. Cell load (expressed as $\log \mathrm{CFU} / \mathrm{mL}$ ) after 24 and $48 \mathrm{~h}$ of incubation of L. sakei Chr82 at $30{ }^{\circ} \mathrm{C}$ in the different DM and growth parameters obtained modelling the growth dynamics in different DM (measure of $\mathrm{OD}_{600}$ ) with the Gompertz equation.

\begin{tabular}{|c|c|c|c|c|c|c|}
\hline \multirow{2}{*}{ Sample } & \multirow{2}{*}{ Time } & \multirow{2}{*}{$\begin{array}{l}\text { Cell Counts } \\
\text { (Log CFU/mL) }\end{array}$} & \multicolumn{4}{|c|}{ Growth Parameters (Gompertz Equation) } \\
\hline & & & $k$ & $A$ & $\mu_{\max }$ & $\lambda$ \\
\hline & $0 \mathrm{~h}$ & $6.94( \pm 0.21)$ & & & & \\
\hline \multirow{2}{*}{$2.5 \mathrm{G}$} & $24 \mathrm{~h}$ & $8.15( \pm 0.23)$ & \multirow{2}{*}{0.044} & \multirow{2}{*}{0.264} & \multirow{2}{*}{0.155} & \multirow{2}{*}{11.457} \\
\hline & $48 \mathrm{~h}$ & $6.67( \pm 0.11)$ & & & & \\
\hline \multirow{2}{*}{$2.5 \mathrm{R}$} & $24 \mathrm{~h}$ & $8.41( \pm 0.16)$ & \multirow{2}{*}{0.046} & \multirow{2}{*}{0.282} & \multirow{2}{*}{0.120} & \multirow{2}{*}{11.570} \\
\hline & $48 \mathrm{~h}$ & $7.62( \pm 0.13)$ & & & & \\
\hline \multirow{2}{*}{$25 \mathrm{G}$} & $24 \mathrm{~h}$ & $8.13( \pm 0.21)$ & \multirow{2}{*}{0.045} & \multirow{2}{*}{1.446} & \multirow{2}{*}{0.280} & \multirow{2}{*}{10.839} \\
\hline & $48 \mathrm{~h}$ & $6.98( \pm 0.13)$ & & & & \\
\hline \multirow{2}{*}{$25 \mathrm{R}$} & $24 \mathrm{~h}$ & $8.10( \pm 0.11)$ & \multirow{2}{*}{0.074} & \multirow{2}{*}{1.151} & \multirow{2}{*}{0.275} & \multirow{2}{*}{11.257} \\
\hline & $48 \mathrm{~h}$ & $6.89( \pm 0.14)$ & & & & \\
\hline
\end{tabular}

\subsection{Organic Acid Content and $p H$}

In Table 3, the organic acids accumulated after 24 and $48 \mathrm{~h}$ of incubation and detected by HPLC are reported.

Table 3. Organic acid content and $\mathrm{pH}$ values of $L$. sakei $\mathrm{Chr} 82$ samples incubated at $30^{\circ} \mathrm{C}$ in the different DMs. Acetic acid concentration is expressed as a difference with respect to the initial amount added in the media as sodium acetate $(24 \mathrm{mM})$.

\begin{tabular}{cccccc}
\hline Sample & Time & $\begin{array}{c}\text { L-Lactic Acid } \\
(\mathbf{m M})\end{array}$ & $\begin{array}{c}\text { D-Lactic Acid } \\
(\mathbf{m M})\end{array}$ & $\begin{array}{c}\text { Acetic Acid } \\
(\mathbf{m M})\end{array}$ & pH \\
\hline \multirow{2}{*}{$2.5 \mathrm{G}$} & $24 \mathrm{~h}$ & $4.25( \pm 0.09)$ & $-*$ & $0.52( \pm 0.20)$ & $5.78( \pm 0.29)$ \\
& $48 \mathrm{~h}$ & $3.88( \pm 0.14)$ & - & $0.62( \pm 0.15)$ & $5.83( \pm 0.16)$ \\
$2.5 \mathrm{R}$ & $24 \mathrm{~h}$ & $1.66( \pm 0.07)$ & - & $2.85( \pm 0.11)$ & $6.17( \pm 0.30)$ \\
& $48 \mathrm{~h}$ & $1.39( \pm 0.04)$ & - & $3.15( \pm 0.09)$ & $6.21( \pm 0.27)$ \\
$25 \mathrm{G}$ & $24 \mathrm{~h}$ & $39.60( \pm 1.98)$ & $0.41( \pm 0.09)$ & $2.58( \pm 0.03)$ & $4.15( \pm 0.17)$ \\
& $48 \mathrm{~h}$ & $43.81( \pm 2.05)$ & $0.39( \pm 0.10)$ & $2.77( \pm 0.28)$ & $4.00( \pm 0.22)$ \\
$25 \mathrm{R}$ & $24 \mathrm{~h}$ & $15.61( \pm 0.90)$ & $1.43( \pm 0.20)$ & $21.00( \pm 0.43)$ & $4.73( \pm 0.21)$ \\
& $48 \mathrm{~h}$ & $16.02( \pm 0.63)$ & $1.09( \pm 0.14)$ & $22.70( \pm 0.67)$ & $4.37( \pm 0.24)$ \\
\hline \multicolumn{5}{c}{$*$ Under the detection limit $(0.1 \mathrm{mM})}$.
\end{tabular}

Considering the lower sugar concentration $(2.5 \mathrm{mM})$, only L-lactate was detected in these samples. In the presence of glucose, its presence (approximately $4 \mathrm{mM}$ ) was accompanied by a lower proportion of acetate ( 0.52 and $0.62 \mathrm{mM}$ after 24 and $48 \mathrm{~h}$, respectively). Higher amounts of acetate (approximately $3 \mathrm{mM}$ ) were produced, as expected, in the presence of ribose. In addition, the molar production of the two acids represented more that $90 \%$ of the theoretical yield. In the presence of ribose, the ratio acetate/lactate was higher than 1, indicating the activation of pathways alternative to homolactic and heterolactic fermentations [19]. 
The presence of fermentable carbohydrates at $25 \mathrm{mM}$ determined the production of more than $40 \mathrm{mM}$ of lactate and small amounts $(2 \mathrm{mM})$ of acetate in the medium added with glucose, while the addition of ribose resulted in the accumulation of lactate (more than $17 \mathrm{mM}$, including L- and D-lactate) and relevant quantities of acetate (more than $21 \mathrm{mM}$ ). In this latter case, the quantitative production of acetate was higher than expected (acetate/lactate molar ratio higher than 1) as a consequence of the activity of secondary pathways. As observed by McLeod et al. [9], L. sakei alters its pyruvate metabolism when grown in the presence of ribose, generating more ATP per ribose unit up-regulating pyruvate decarboxylases and pyruvate dehydrogenases which can bring to the accumulation of acetate [19].

The presence of glucose compared with ribose always determined a lower $\mathrm{pH}$ (Table 3), and after $48 \mathrm{~h}$, values of 5.83 vs. 6.21 were found with the addition of the sugars at $2.5 \mathrm{mM}$, while at $25 \mathrm{mM}$, the $\mathrm{pH}$ values measured were 4.00 and 4.37 for glucose and ribose, respectively.

\subsection{Amino Acids Quantification}

It is well known that $L$. sakei, because of its adaptation to meat environments, is auxotrophic for 18 amino acids [8]. The study of the variations in the amino acid content in a defined medium is important to elucidate how this species uses these molecules. In the first instance, they are used to assemble all the proteins (and enzymes) necessary to sustain growth and multiplication. However, it is interesting to evidence amino acid alternative uses in the perspective of explaining the high persistence of $L$. sakei cells in habitats, such as fermented sausages, in which fermentable sugars are rapidly depleted. In a previous work, Montanari et al. [6] described amino acid variations due to the resuspension of resting cells in a defined medium. In the present research, the changes in amino acid concentration are studied after L. sakei growth, and the influence of cell metabolism on each amino acid, as revealed by HPLC analyses, is shown in Table 4 .

The concentration of many amino acids after 24 and $48 \mathrm{~h}$ of incubation showed small variations with respect to the initial level. Aspartate, alanine, valine, lysine and leucine were always consumed in an amount lower than $20 \%$ of the initial concentration. Smaller variations were observed for isoleucine, tyrosine, threonine and glycine. Phenylalanine was accumulated (up to $17 \%$ of the initial concentration) in all the conditions tested with a trend similar to that observed by McLeod et al. [5]. Glutamic acid, generally consumed in all the other conditions, was accumulated in the presence of glucose $25 \mathrm{mM}$. The remaining amino acids were subjected to more relevant variations (Figure 1).

The use of arginine to produce ATP through the ADI pathway has been well studied in L. sakei [20]. However, different patterns of decrease have been observed among strains [5,6]. In this case, glucose retarded arginine depletion, even if after $48 \mathrm{~h}$, the presence at $2.5 \mathrm{mM}$ of this sugar caused a high consumption of this amino acid (Figure 1a). By contrast, the presence of ribose as a fermentable sugar determined a rapid and massive consumption of this amino acid, independently of the ribose concentration.

The activation of the ADI pathway is considered crucial to allow the survival of this species in meat environments. Some strains possess a second putative ADI pathway, which improves their ability to take advantages from the high amounts of arginine in meats [5]. This activity is confirmed by the accumulation of ornithine (Figure 1b). Ornithine is the final product of the ADI pathway and was produced in higher amounts in the presence of ribose, particularly $2.5 \mathrm{mM}$. The absence of a correspondence between arginine consumption and ornithine production could be attributed to the ability of this strain to decarboxylate this amino acid. In fact, only L. sakei Chr82, among the six strains tested by Montanari et al. [6], was able to produce putrescine from the decarboxylation of ornithine. However, in the conditions adopted in the present study, this biogenic amine was never detected. 
Table 4. Amino acid concentrations (mM) detected by HPLC in DM after 24 and $48 \mathrm{~h}$ of incubation of L. sakei Chr82 at $30{ }^{\circ} \mathrm{C}$ in the different DMs. In brackets, the relative variations (as percentage) with respect to the initial concentration are reported.

\begin{tabular}{|c|c|c|c|c|c|c|c|c|c|c|c|c|c|c|c|c|c|c|}
\hline & & Asp & Ser + Asg & Glu & Gly & His + Glm & Arg & Thr & Ala & Pro & Cys & Tyr & Val & Met & Lys & Ile & Leu & Phe \\
\hline \multicolumn{2}{|c|}{$\begin{array}{c}\text { Initial } \\
\text { concentration }\end{array}$} & 1.50 & 3.42 & 1.36 & 2.66 & 2.66 & 1.15 & 1.68 & 2.24 & 1.74 & 1.65 & 1.10 & 1.71 & 1.34 & 1.37 & 1.52 & 1.52 & 1.21 \\
\hline Sample & Time & & & & & & & & & & & & & & & & & \\
\hline \multirow[t]{2}{*}{$2.5 \mathrm{G}$} & $24 \mathrm{~h}$ & $\begin{array}{c}1.39 \\
(-7.49)\end{array}$ & $\begin{array}{c}3.15 \\
(-7.94)\end{array}$ & $\begin{array}{c}1.27 \\
(-6.53)\end{array}$ & $\begin{array}{c}2.91 \\
(9.53)\end{array}$ & $\begin{array}{c}2.25 \\
(-15.27)\end{array}$ & $\begin{array}{c}1.01 \\
(-12.00)\end{array}$ & $\begin{array}{c}1.79 \\
(6.57)\end{array}$ & $\begin{array}{c}2.12 \\
(-1.09)\end{array}$ & $\begin{array}{c}1.92 \\
(10.49)\end{array}$ & $\begin{array}{c}2.18 \\
(32.02)\end{array}$ & $\begin{array}{c}1.11 \\
(0.85)\end{array}$ & $\begin{array}{c}1.84 \\
(7.68)\end{array}$ & $\begin{array}{c}1.27 \\
(-5.45)\end{array}$ & $\begin{array}{c}1.36 \\
(-0.45)\end{array}$ & $\begin{array}{c}1.50 \\
(-1.54)\end{array}$ & $\begin{array}{c}1.39 \\
(-8.51)\end{array}$ & $\begin{array}{c}1.28 \\
(6.02)\end{array}$ \\
\hline & $48 \mathrm{~h}$ & $\begin{array}{c}1.27 \\
(-15.53)\end{array}$ & $\begin{array}{c}2.65 \\
(-22.41)\end{array}$ & $\begin{array}{c}1.07 \\
(-21.36)\end{array}$ & $\begin{array}{c}2.50 \\
(-5.97)\end{array}$ & $\begin{array}{c}1.85 \\
(-30.44)\end{array}$ & $\begin{array}{c}0.29 \\
(-74.57)\end{array}$ & $\begin{array}{c}1.80 \\
(7.29)\end{array}$ & $\begin{array}{c}2.03 \\
(-9.22)\end{array}$ & $\begin{array}{c}1.80 \\
(3.20)\end{array}$ & $\begin{array}{c}2.45 \\
(48.56)\end{array}$ & $\begin{array}{c}1.04 \\
(-5.83)\end{array}$ & $\begin{array}{c}1.66 \\
(-2.90)\end{array}$ & $\begin{array}{c}0.69 \\
(-48.88)\end{array}$ & $\begin{array}{c}1.44 \\
(4.96)\end{array}$ & $\begin{array}{c}1.53 \\
(0.68)\end{array}$ & $\begin{array}{c}1.49 \\
(-2.22)\end{array}$ & $\begin{array}{c}1.41 \\
(16.51)\end{array}$ \\
\hline \multirow[t]{2}{*}{$2.5 \mathrm{R}$} & $24 \mathrm{~h}$ & $\begin{array}{c}1.32 \\
(-12.26)\end{array}$ & $\begin{array}{c}2.98 \\
(-13.00)\end{array}$ & $\begin{array}{c}1.18 \\
(-13.50)\end{array}$ & $\begin{array}{c}2.81 \\
(5.61)\end{array}$ & $\begin{array}{c}2.13 \\
(-19.94)\end{array}$ & $\begin{array}{c}0.10 \\
(-91.57)\end{array}$ & $\begin{array}{c}1.65 \\
(-1.87)\end{array}$ & $\begin{array}{c}2.21 \\
(-1.38)\end{array}$ & $\begin{array}{c}1.78 \\
(2.09)\end{array}$ & $\begin{array}{c}2.01 \\
(21.78)\end{array}$ & $\begin{array}{c}1.10 \\
(0.12)\end{array}$ & $\begin{array}{c}1.69 \\
(-0.96)\end{array}$ & $\begin{array}{c}1.36 \\
(1.18)\end{array}$ & $\begin{array}{c}1.36 \\
(-0.67)\end{array}$ & $\begin{array}{c}1.58 \\
(3.63)\end{array}$ & $\begin{array}{c}1.43 \\
(-6.03)\end{array}$ & $\begin{array}{c}1.26 \\
(4.53)\end{array}$ \\
\hline & $48 \mathrm{~h}$ & $\begin{array}{c}1.44 \\
(-11.04) \\
\end{array}$ & $\begin{array}{c}2.58 \\
(-24.42) \\
\end{array}$ & $\begin{array}{c}1.08 \\
(-20.47)\end{array}$ & $\begin{array}{c}2.48 \\
(-6.82)\end{array}$ & $\begin{array}{c}1.79 \\
(-32.85) \\
\end{array}$ & $\begin{array}{c}0.19 \\
(-83.76) \\
\end{array}$ & $\begin{array}{c}1.71 \\
(2.08)\end{array}$ & $\begin{array}{c}2.02 \\
(-10.03) \\
\end{array}$ & $\begin{array}{c}1.77 \\
(1.75)\end{array}$ & $\begin{array}{c}2.53 \\
(53.09)\end{array}$ & $\begin{array}{c}1.14 \\
(3.93)\end{array}$ & $\begin{array}{c}1.62 \\
(-5.05)\end{array}$ & $\begin{array}{c}0.94 \\
(-30.22) \\
\end{array}$ & $\begin{array}{c}1.41 \\
(2.99)\end{array}$ & $\begin{array}{c}1.53 \\
(0.39)\end{array}$ & $\begin{array}{c}1.50 \\
(-1.58)\end{array}$ & $\begin{array}{c}1.34 \\
(10.72) \\
\end{array}$ \\
\hline \multirow[t]{2}{*}{$25 \mathrm{G}$} & $24 \mathrm{~h}$ & $\begin{array}{c}1.30 \\
(-4.00)\end{array}$ & $\begin{array}{c}1.21 \\
(-64.72)\end{array}$ & $\begin{array}{c}1.73 \\
(27.56)\end{array}$ & $\begin{array}{c}2.71 \\
(1.78)\end{array}$ & $\begin{array}{c}1.45 \\
(-45.33)\end{array}$ & $\begin{array}{c}0.90 \\
(-21.38)\end{array}$ & $\begin{array}{c}1.56 \\
(-6.93)\end{array}$ & $\begin{array}{c}1.92 \\
(-14.09)\end{array}$ & $\begin{array}{c}1.69 \\
(-3.07)\end{array}$ & $\begin{array}{c}1.75 \\
(6.31)\end{array}$ & $\begin{array}{c}1.07 \\
(-2.87)\end{array}$ & $\begin{array}{c}1.59 \\
(-7.27)\end{array}$ & $\begin{array}{c}1.31 \\
(-2.42)\end{array}$ & $\begin{array}{c}1.23 \\
(-9.96)\end{array}$ & $\begin{array}{c}1.59 \\
(4.93)\end{array}$ & $\begin{array}{c}1.39 \\
(-8.25)\end{array}$ & $\begin{array}{c}1.42 \\
(17.71)\end{array}$ \\
\hline & $48 \mathrm{~h}$ & $\begin{array}{c}1.41 \\
(-13.27) \\
\end{array}$ & $\begin{array}{c}0.89 \\
(-73.95) \\
\end{array}$ & $\begin{array}{c}1.63 \\
(19.88)\end{array}$ & $\begin{array}{c}2.33 \\
(-12.43) \\
\end{array}$ & $\begin{array}{c}1.10 \\
(-58.54) \\
\end{array}$ & $\begin{array}{c}0.80 \\
(-30.78) \\
\end{array}$ & $\begin{array}{c}1.36 \\
(-19.13) \\
\end{array}$ & $\begin{array}{c}1.73 \\
(-22.80) \\
\end{array}$ & $\begin{array}{c}1.75 \\
(0.81) \\
\end{array}$ & $\begin{array}{c}2.00 \\
(21.05) \\
\end{array}$ & $\begin{array}{c}1.02 \\
(-7.05) \\
\end{array}$ & $\begin{array}{c}1.50 \\
(-12.17) \\
\end{array}$ & $\begin{array}{c}1.26 \\
(-6.27) \\
\end{array}$ & $\begin{array}{c}1.10 \\
(-19.61)\end{array}$ & $\begin{array}{c}1.39 \\
(-8.81) \\
\end{array}$ & $\begin{array}{c}1.45 \\
(-4.67) \\
\end{array}$ & $\begin{array}{c}1.32 \\
(9.38)\end{array}$ \\
\hline \multirow[t]{2}{*}{$25 \mathrm{R}$} & $24 \mathrm{~h}$ & $\begin{array}{c}1.28 \\
(-14.55)\end{array}$ & $\begin{array}{c}2.05 \\
(-40.17)\end{array}$ & $\begin{array}{c}1.33 \\
(-2.17)\end{array}$ & $\begin{array}{c}2.62 \\
(-1.41)\end{array}$ & $\begin{array}{c}1.80 \\
(-32.31)\end{array}$ & $\begin{array}{c}0.09 \\
(-92.08)\end{array}$ & $\begin{array}{c}1.77 \\
(5.53)\end{array}$ & $\begin{array}{c}2.02 \\
(-9.78)\end{array}$ & $\begin{array}{c}1.75 \\
(0.30)\end{array}$ & $\begin{array}{c}1.43 \\
(-13.05)\end{array}$ & $\begin{array}{c}1.01 \\
(-7.88)\end{array}$ & $\begin{array}{c}1.59 \\
(-6.93)\end{array}$ & $\begin{array}{c}1.15 \\
(-14.50)\end{array}$ & $\begin{array}{c}1.21 \\
(-11.82)\end{array}$ & $\begin{array}{c}1.49 \\
(-2.04)\end{array}$ & $\begin{array}{c}1.46 \\
(-4.22)\end{array}$ & $\begin{array}{c}1.35 \\
(11.82)\end{array}$ \\
\hline & $48 \mathrm{~h}$ & $\begin{array}{c}1.20 \\
(-20.06)\end{array}$ & $\begin{array}{c}1.83 \\
(-46.41)\end{array}$ & $\begin{array}{c}1.18 \\
(-13.32)\end{array}$ & $\begin{array}{c}2.35 \\
(-11.60)\end{array}$ & $\begin{array}{c}1.50 \\
(-43.72)\end{array}$ & $\begin{array}{c}0.12 \\
(-89.31)\end{array}$ & $\begin{array}{c}1.64 \\
(-2.14)\end{array}$ & $\begin{array}{c}1.86 \\
(-17.08)\end{array}$ & $\begin{array}{c}1.80 \\
(3.60)\end{array}$ & $\begin{array}{c}1.57 \\
(-5.09)\end{array}$ & $\begin{array}{c}1.08 \\
(-2.27)\end{array}$ & $\begin{array}{c}1.52 \\
(-11.15)\end{array}$ & $\begin{array}{c}1.04 \\
(-22.76)\end{array}$ & $\begin{array}{c}1.09 \\
(-20.45)\end{array}$ & $\begin{array}{c}1.34 \\
(-11.72)\end{array}$ & $\begin{array}{c}1.37 \\
(-9.93)\end{array}$ & $\begin{array}{c}1.32 \\
(9.45)\end{array}$ \\
\hline
\end{tabular}




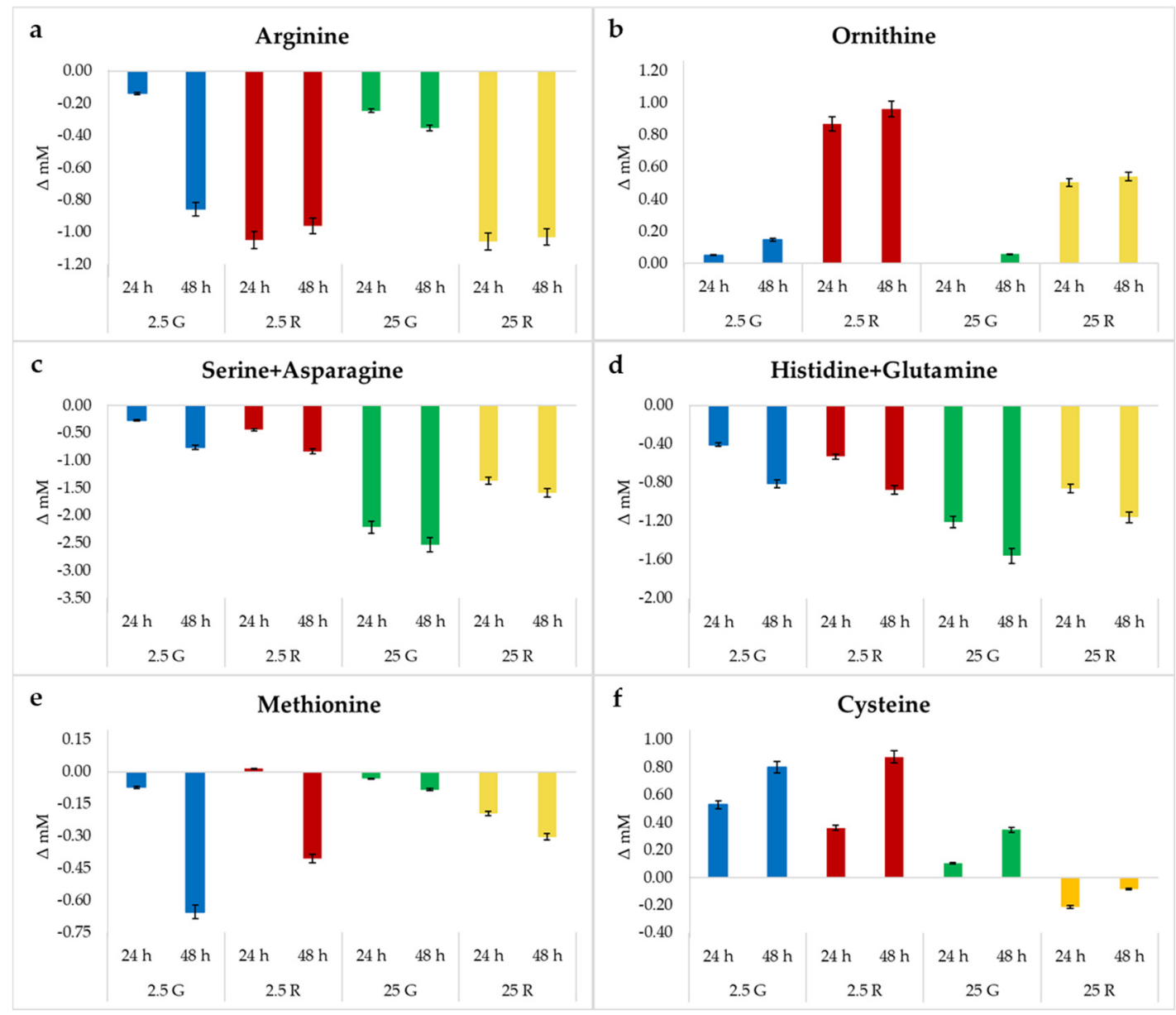

Figure 1. Variation in the amounts of amino acids characterized by the most relevant modification after 24 and $48 \mathrm{~h}$ of incubation at $30^{\circ} \mathrm{C}$ of L. sakei Chr82 with respect to the initial concentration in the DM, and ornithine production. The standard deviations are reported.

The sum of serine and asparagine (not separated under the adopted HPLC analytical protocol) showed a drastic decrease, especially in the samples containing a high sugar concentration and after $48 \mathrm{~h}$ of incubation (Figure 1c). Serine can be used to supply pyruvate, which can then be used to produce energy through the PFL or POX pathways [21]. The conversion of serine into pyruvate has been described in Pediococcus pentosaceus as the result of the activity of a serine dehydratase [22], while Lactobacillus plantarum could metabolize serine with the production of formate, succinate and acetate [23]. McLeod et al. [5] showed a high use of serine and asparagine in L. sakei strains grown under glucose limiting conditions. Among the six L. sakei strains tested by Montanari et al. [6] under resting conditions, the strain Chr82 was the most efficient in serine + aspargine uptake in the absence of fermentable sugars. The decrease was higher in the sample containing glucose, in contrast to the trend observed for arginine.

Further, the consumption of histidine + glutamine (not separated under the adopted HPLC analytical protocol) was higher in the media containing glucose (Figure 1d). The resuspension of resting cells of the same strain in the DM did not markedly change the concentration of these amino acids. By contrast, growing cells decreased the concentration of these amino acids, especially after $48 \mathrm{~h}$ and when glucose was present in the medium. McLeod et al. [5] showed a strong decrease in glutamine during a continuous cultivation in a glucose-limited medium inoculated with two L. sakei strains, while the concentration of histidine was scarcely affected.

Finally, the sulfur amino acids methionine and cysteine showed a correlated trend (Figure 1e,f). Relevant diminutions of methionine were observed after $48 \mathrm{~h}$ in the samples with $2.5 \mathrm{mM}$ of both 
sugars. However, these decreases were accompanied by concomitant increases in cysteine. Only the samples containing ribose $25 \mathrm{mM}$ presented a simultaneous decrease in both amino acids.

\subsection{Flow Cytometric Analysis}

The same samples were also subjected to flow cytometric (FCM) analysis to define some parameters linked to cell viability. Each sample was labeled with SYBR-Green I and propidium iodide (PI) in a 1:1 ratio. This dual staining allowed to discriminate three sub-populations: alive, damaged or dead cells. The results are shown in Figure 2.

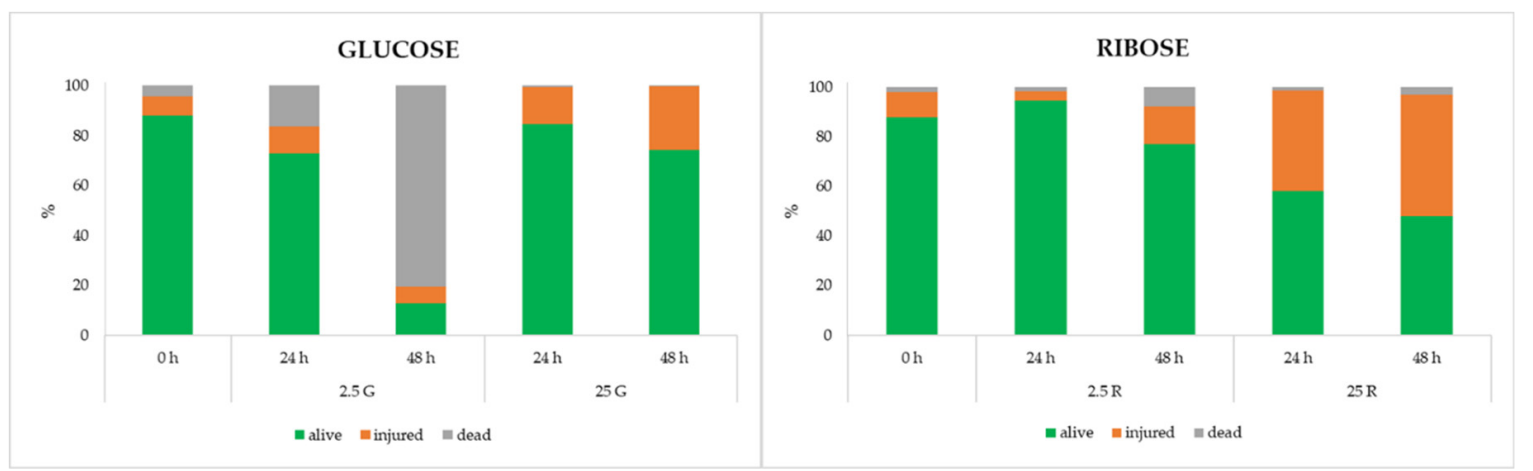

Figure 2. Distribution of alive, damaged and dead cells of L. sakei Chr82 after 24 and $48 \mathrm{~h}$ of incubation at $30{ }^{\circ} \mathrm{C}$ in different DMs. The data are reported as the relative frequency of the total population obtained by flow cytometric (FCM) analysis with dual staining (SYBR-Green I and PI).

In the samples containing glucose, a higher viability in the cells grown in the presence of $25 \mathrm{mM}$ of this sugar was generally observed. The percentage of cells recognized as alive was $84.6 \%$ and $74.4 \%$, after 24 and $48 \mathrm{~h}$, respectively. At the same sampling times, the injured cells passed from $7.6 \%$ to $14.9 \%$ and $25.5 \%$ and dead cells from $4.28 \%$ to $0.5 \%$ and $0.1 \%$, respectively. The presence of a limited amount of glucose $(2.5 \mathrm{mM})$ determined a drastic increase in the dead cells (approximately $18 \%$ after $24 \mathrm{~h}$ and $80 \%$ after $48 \mathrm{~h})$. When the ribose was added at the higher concentration $(25 \mathrm{mM})$, the number of dead cells remained comparable to those observed in the presence of glucose, but the portion of damaged cells was much more relevant, already starting from $24 \mathrm{~h}$ of incubation. Conversely, the addition of ribose $2.5 \mathrm{mM}$ resulted, after $48 \mathrm{~h}$, in a higher viability if compared with the sample added with the same amount of glucose.

Regarding the membrane depolarization, expressed as fluorescence of $\mathrm{DiBAC}_{4}(3)$, the results obtained for the sugars at the two concentrations (Figure 3) showed that this parameter is inversely proportional to the media $\mathrm{pH}$. In fact, in the presence of the higher sugar concentrations, and therefore with the lowest media $\mathrm{pH}$ values (4 in the presence of glucose and 4.6 in the presence of ribose), cell membrane depolarization was greater. In the $2.5 \mathrm{G}$ and $2.5 \mathrm{R}$ samples, characterized by higher $\mathrm{pH}$ values (about 5.8 in the presence of glucose and 6.2 in the presence of ribose), the depolarization degree was lower.

Finally, the results of membrane permeability (Figure 4) showed higher values in the presence of glucose $2.5 \mathrm{mM}$, while the trend was opposite in the presence of ribose, where the membrane permeability was higher in the presence of the higher concentration of this sugar. 


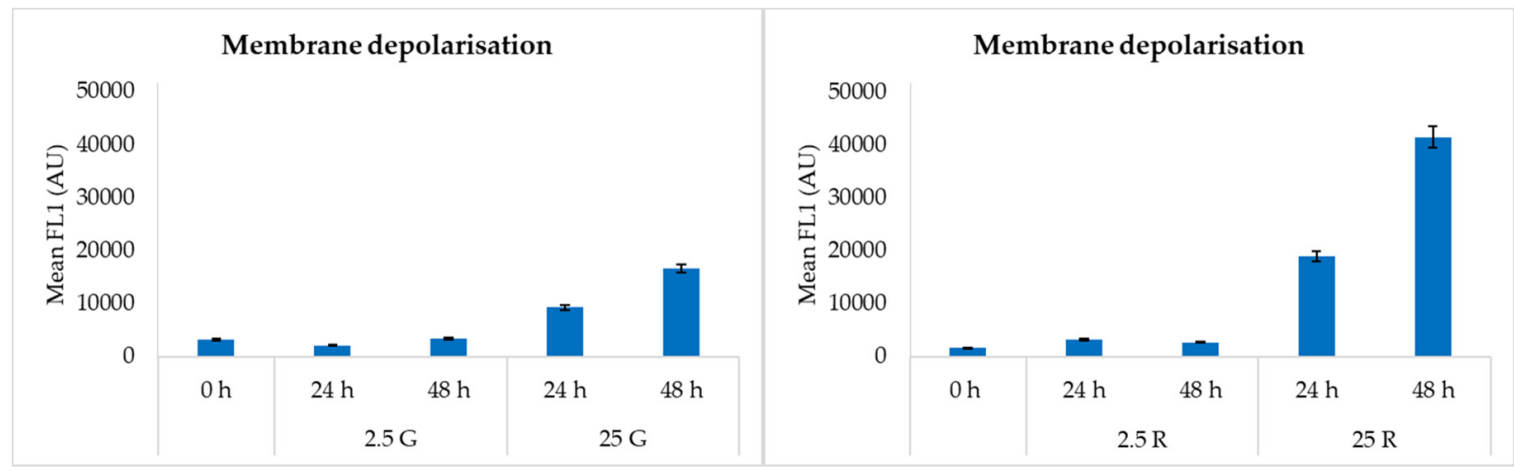

Figure 3. FCM analysis related to membrane depolarization in L. sakei Chr82 after 24 and 48 h of incubation at $30{ }^{\circ} \mathrm{C}$ in different DMs. Data are reported as mean fluorescence of $\mathrm{DiBAC}_{4}(3)$ dye (arbitrary unit, AU).

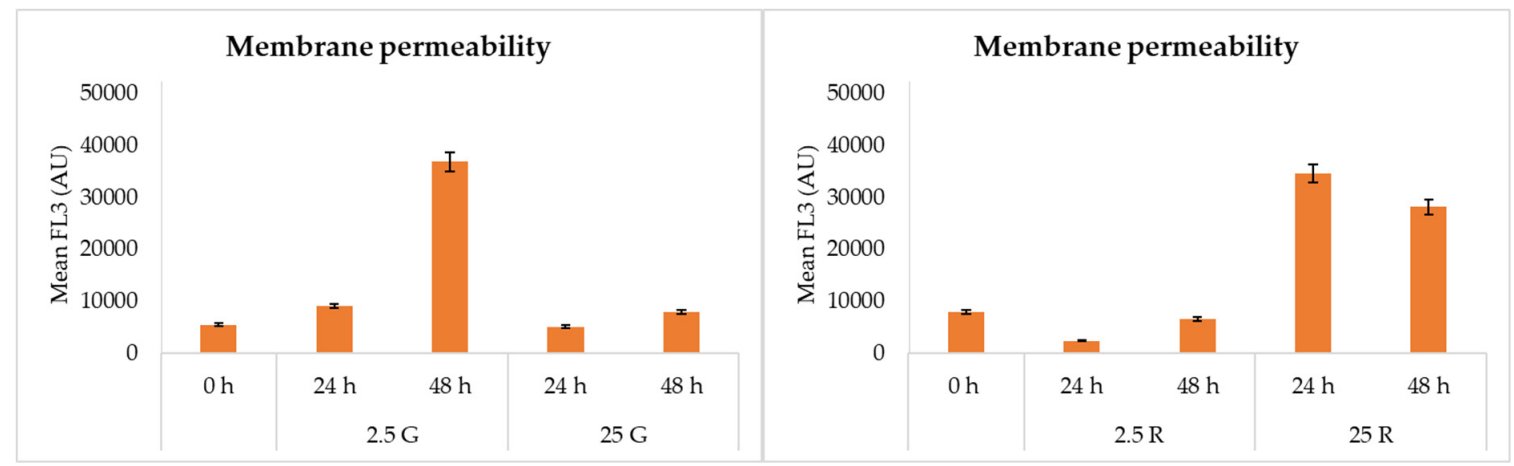

Figure 4. FCM analysis related to membrane permeability in L. sakei Chr82 after 24 and $48 \mathrm{~h}$ of incubation at $30{ }^{\circ} \mathrm{C}$ in different DMs. Data are reported as mean fluorescence of the propidium iodide (PI) (arbitrary unit, AU).

\subsection{Untargeted Metabolomics Analysis by ${ }^{1} H-N M R$}

With the aim to have a deeper insight in the metabolomic responses of the strain L. sakei Chr82, the same samples were further analyzed applying a quantification protocol based on ${ }^{1} \mathrm{H}-\mathrm{NMR}$. An example of portions of the ${ }^{1} \mathrm{H}-\mathrm{NMR}$ spectrum obtained from one representative sample is reported in Supplementary Materials Figure S2. Regarding the amino acid concentration, the correlation between the NMR and HPLC results was satisfying, as demonstrated by the regression analysis reported in Figure 5, characterized by a high $R^{2}(0.8702)$, an intercept of 0.1542 and an angular coefficient close to 1 (1.1372). Previous works supported the suitability of the ${ }^{1} \mathrm{H}-\mathrm{NMR}$ approach: for example, Biagioli et al. [24] were able to observe divergent metabolic activities of two batches of the same probiotic preparation; Parolin et al. [25] identified the metabolome traits distinguishing vaginal lactobacilli with different anti-candida activity; and Picone et al. [26] followed the adaptation of Escherichia coli 555 to increasing doses of carvacrol.

NMR data were focused, at a first instance, to the evaluation of the amino acids not separated by the HPLC analysis, i.e., serine + asparagine and histidine + glutamine. The results regarding these amino acids, expressed as concentration variation, are reported in Figures 6 and 7.

Taking into consideration serine + asparagine, the total decrease in these two molecules detected with the two methods were comparable. However, the ${ }^{1} \mathrm{H}-\mathrm{NMR}$ approach indicated that the main decrease concerned serine (Figure 6), confirming the hypothesis that this amino acid can provide a supply of pyruvate, which can be addressed to alternative metabolic pathways that are important for when available sugars become a limiting factor. Liu et al. [27] proved the central role of pyruvate deriving from serine in L. plantarum metabolism, demonstrating that it was involved in the regeneration of NADH and in the production of ATP, acetate, formate, ethanol, acetoin, diacetyl and 2-3-butanediol. 


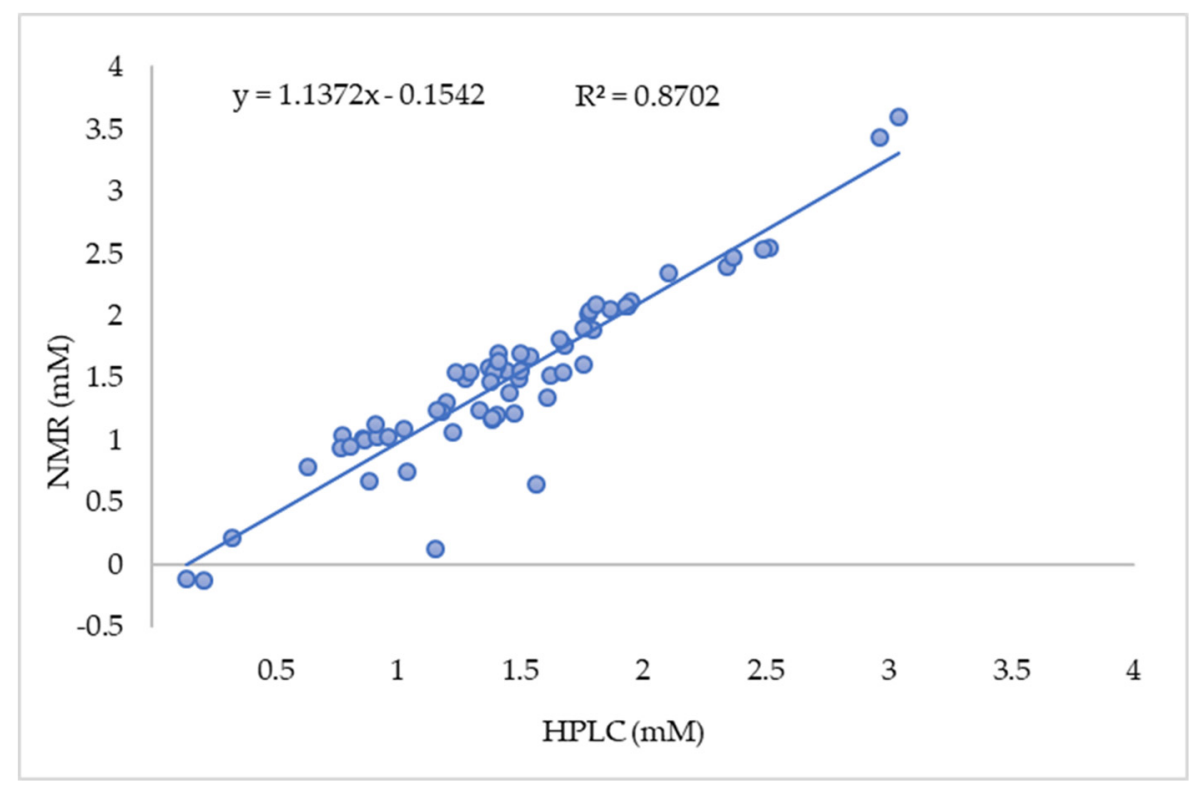

Figure 5. Correlation matrix between ${ }^{1} \mathrm{H}-\mathrm{NMR}$ and HPLC results (expressed as mM). In the figure are reported the correlation line between NMR results (y) and HPLC results ( $\mathrm{x}$ ) and the correlation coefficient $\left(\mathrm{R}^{2}\right)$.

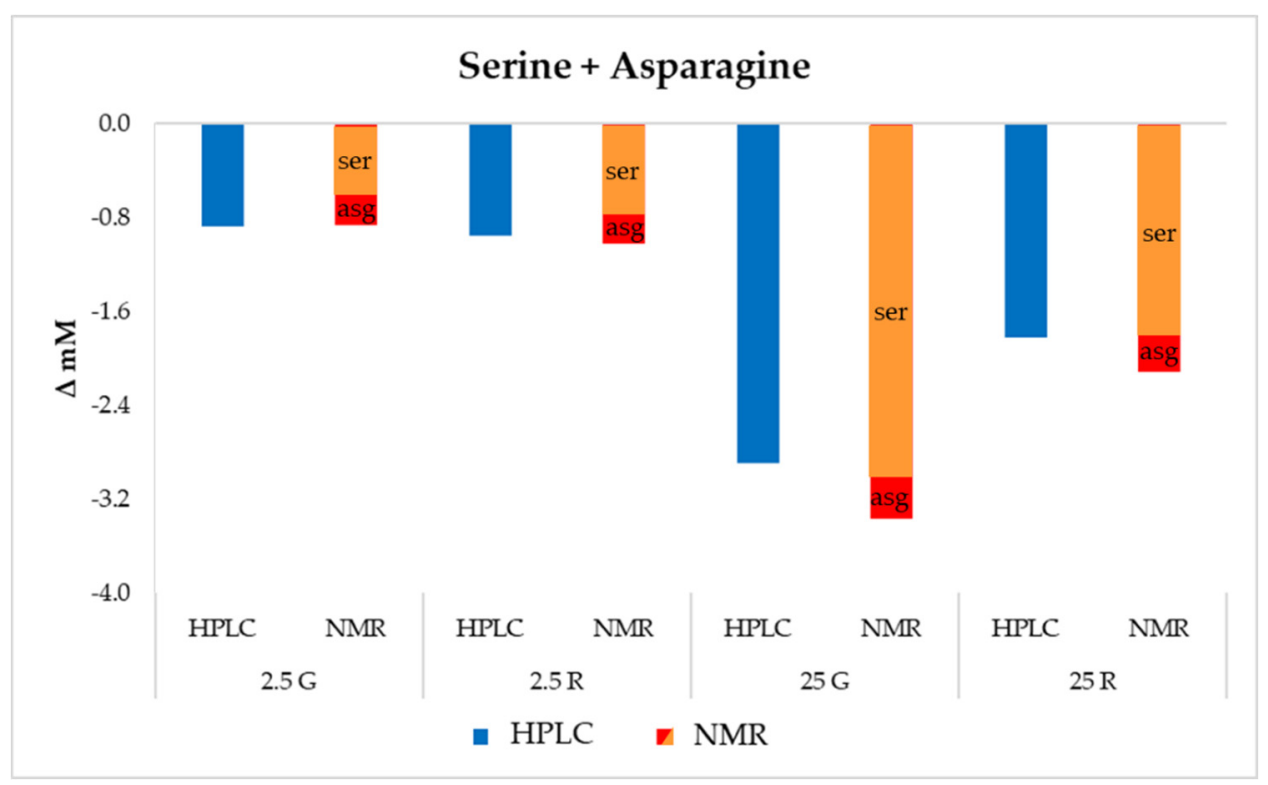

Figure 6. Variation $(\mathrm{mM})$ in serine and asparagine with respect to the initial concentration in the different DMs after $48 \mathrm{~h}$ of incubation.

Lower concordance was observed for the data of histidine + glutamine (Figure 7). While in the presence of a low sugar concentration, the ${ }^{1} \mathrm{H}-\mathrm{NMR}$ analysis reported lower amounts of amino acids uptake if compared with the HPLC results, and an opposite trend characterized the samples with the higher glucose and ribose concentration. In any case, according to the ${ }^{1} \mathrm{H}-\mathrm{NMR}$ results, the consumption of the two amino acids was reduced at a similar rate in the presence of $2.5 \mathrm{mM}$ of the sugars, while, when the sugars were present at high concentration, histidine was depleted much more than glutamine. 


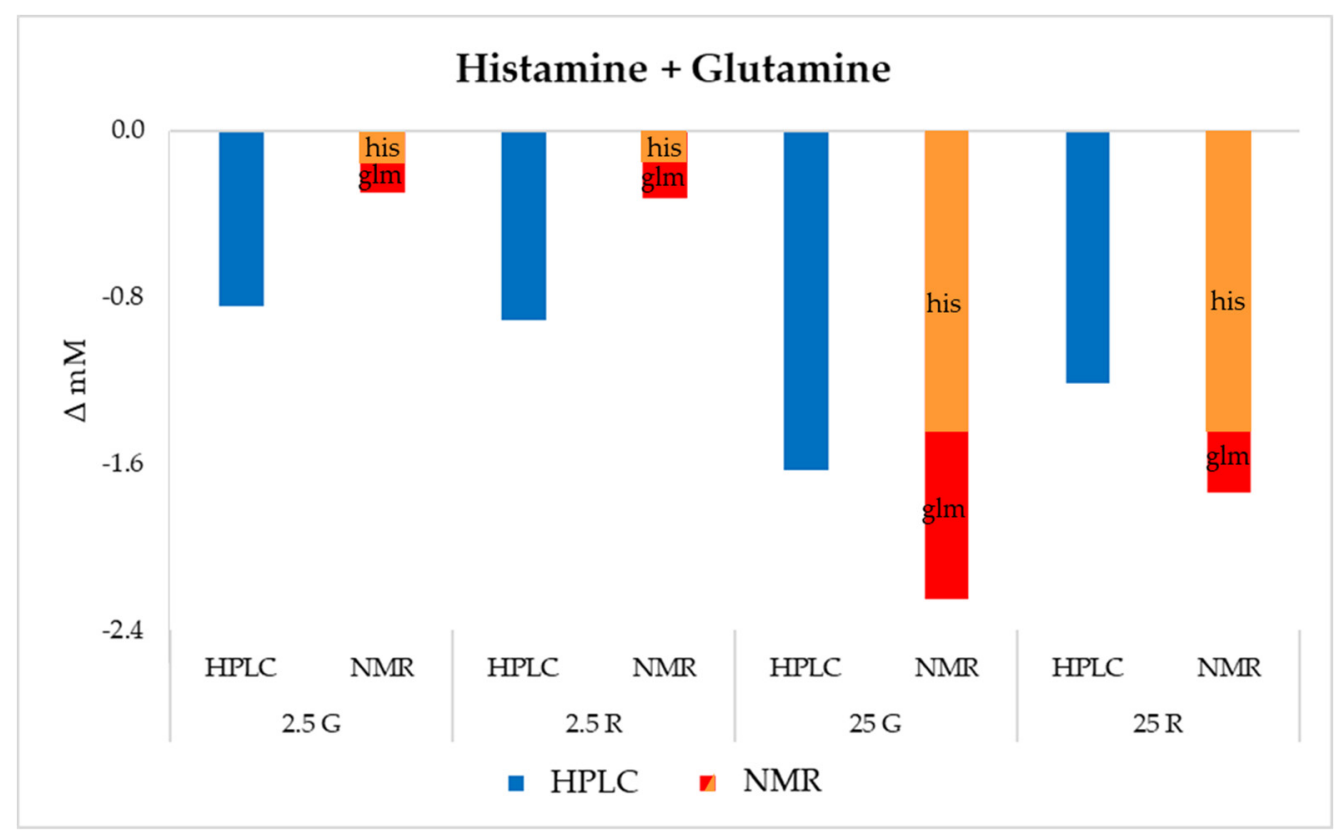

Figure 7. Variation $(\mathrm{mM})$ in histidine and glutamine with respect to the initial concentration in the different DMs after $48 \mathrm{~h}$ of incubation.

In addition to the amino acid content, the untargeted ${ }^{1} \mathrm{H}-\mathrm{NMR}$ protocol applied allowed the detection of other metabolic compounds (Table 5).

Table 5. Concentration (expressed as $\mathrm{mM}$ ) of some metabolic compounds detected by ${ }^{1} \mathrm{H}-\mathrm{NMR}$ after $48 \mathrm{~h}$ of L. sakei Chr82 incubation at $30^{\circ} \mathrm{C}$ in different DMs.

\begin{tabular}{cccccc}
\hline & Ethanol & Acetoin & 2,3-Butanediol & Glucose & Ribose \\
\hline $2.5 \mathrm{G}$ & 0.01 & 0.10 & 0.01 & $-*$ & - \\
$2.5 \mathrm{R}$ & 0.01 & 0.15 & 0.01 & - & - \\
$25 \mathrm{G}$ & 0.03 & 0.14 & 0.06 & 0.14 & - \\
$25 \mathrm{R}$ & 0.01 & 0.21 & 0.19 & - & 0.15 \\
\hline \multicolumn{7}{c}{ * Under the detection limit $(0.01 \mathrm{mM})}$.
\end{tabular}

Regarding sugars, they resulted in being completely depleted in the media in which they were added at $2.5 \mathrm{mM}$, while in the samples added with $25 \mathrm{mM}$, small residual quantities (approximately $0.15 \mathrm{mM}$ ) were detected. Further, ethanol was detected in extremely low amounts, indicating that the secondary metabolic pathways activated by L. sakei Chr82 were mainly addressed towards the production of acetic acid which allows the production of energy rather than the regeneration of reduced NADH. The production of acetoin and 2,3-butanediol was higher in the samples containing a higher sugar concentration, particularly in the sample with ribose.

\section{Conclusions}

The results obtained in this work increase the knowledge on the physiological and metabolic responses of $L$. sakei in relation to different sugar amounts. Indeed, the combined use of HPLC and ${ }^{1} \mathrm{H}-\mathrm{NMR}$ approaches allowed to better elucidate the consumption of amino acids and the resulting metabolites produced during incubation.

As expected, higher concentrations of glucose or ribose induced higher growth performances, acidification of the growth medium and accumulation of lactic and acetic acids.

The flow cytometric analysis evidenced a different physiological adaptation to the conditions; in fact, even if cells grown on glucose at a high concentration had a high viability, the same sugar in 
low amounts induced the presence of dead cells, while ribose determined the higher percentage of injured cells, but only few cells were recognized as dead also when this pentose was present at $2.5 \mathrm{mM}$.

The analysis of amino acids confirmed the rapid depletion of specific amino acids, mainly arginine, whose consumption was higher in the presence of ribose and resulted in the production of ornithine. Other amino acids highly consumed by this strain were serine, asparagine, glutamine and histidine. Since the HPLC protocol adopted was not able to separate these metabolites (co-elution of serine + asparagine and glutamine + histidine), ${ }^{1} \mathrm{H}-\mathrm{NMR}$ analysis in this case was helpful to discriminate the single metabolites, allowing to evidence a higher consumption of serine, especially when sugars were present at an optimal concentration. This consumption of serine confirmed other findings reported in the literature for lactic acid bacteria, i.e., the use of this amino acid as a source of pyruvate, which can then be used to produce energy through secondary pathways.

The untargeted ${ }^{1} \mathrm{H}-\mathrm{NMR}$ analysis performed on the samples with the aim to set up a fast method to simultaneously quantify amino acids, sugars, organic acids and other molecules was successful. This approach resulted as indeed suitable and very promising to evaluate the metabolic response of L. sakei in terms of the consumption and accumulation of specific metabolites.

This information can be helpful to optimize the use of this species as a starter culture for the industrial production of fermented sausages, since stressful conditions can affect the microbial technological performances or induce the activation of specific metabolic pathways, whose final products can have a significant impact on the sensorial features of the fermented sausages obtained.

Supplementary Materials: The following are available online at http://www.mdpi.com/2304-8158/9/6/720/s1, Figure S1: Growth curves of L. sakei Chr82 at $30{ }^{\circ} \mathrm{C}$ under different conditions. In the square the Gompertz parameters are reported. Points: experimental data; lines: fitting curves as predicted by Gompertz equation, Figure S2. Portions of 1H-NMR spectrum from L. sakei Chr82 inoculated in DM with $25 \mathrm{mM}$ of glucose reporting, for the molecules listed in Tables 4 and 5, the signals employed for quantification. The exact extremes of the signals are represented by dashed lines (p. 14).

Author Contributions: Conceptualization, G.T. and F.G.; Literature data collection, G.T. and F.B.; Microbiological, HPLC and FCM analyses, C.M. and F.B.; NMR analyses, L.L.; Writing—original draft preparation, G.T. and F.B.; Writing-review and editing, C.M., F.G. and L.L. All authors have read and agreed to the published version of the manuscript.

Funding: This research received no external funding.

Conflicts of Interest: The authors declare no conflict of interest.

\section{References}

1. Cocconcelli, P.S.; Fontana, C. Starter cultures for meat fermentation. In Handbook of Meat Processing; Toldrá, F., Ed.; Blackwell Publishing: Ames, IA, USA, 2010; pp. 199-218, ISBN 9780813820897.

2. Chaillou, S.; Lucquin, I.; Najjari, A.; Zagorec, M.; Champomier-Vergès, M.C. Population genetics of Lactobacillus sakei reveals three lineages with distinct evolutionary histories. PLoS ONE 2013, 8, e73253. [CrossRef]

3. McLeod, A.; Nyquistb, O.N.; Snipenb, L.; Naterstada, K.; Axelsson, L. Diversity of Lactobacillus sakei strains investigated by phenotypic and genotypic methods. Syst. Appl. Microbiol. 2008, 31, 393-403. [CrossRef]

4. Rimaux, T.; Vrancken, G.; Vuylsteke, B.; De Vuyst, L.; Leroy, F. The pentose moiety of adenosine and inosine is an important energy source for the fermented-meat starter culture Lactobacillus sakei CTC 494. Appl. Environ. Microbiol. 2011, 77, 6539-6550. [CrossRef]

5. McLeod, A.; Mosleth, E.F.; Rud, I.; Branco dos Santos, F.; Snipen, L.; Liland, K.H.; Axelsson, L. Effects of glucose availability in Lactobacillus sakei; metabolic change and regulation of the proteome and transcriptome. PLoS ONE 2017, 12, e0187542. [CrossRef] [PubMed]

6. Montanari, C.; Barbieri, F.; Magnani, M.; Grazia, L.; Gardini, F.; Tabanelli, G. Phenotypic diversity of Lactobacillus sakei strains. Front. Microbiol. 2018, 9, 2003. [CrossRef] [PubMed] 
7. Chaillou, S.; Daty, M.; Baraige, F.; Dudez, A.M.; Anglade, P.; Jones, R.; Alpert, C.A.; Champomier-Vergès, M.C.; Zagorec, M. Intra-species genomic diversity and natural population structure of the meat borne lactic acid bacterium Lactobacillus sakei. Appl. Environ. Microbiol. 2009, 75, 970-980. [CrossRef]

8. Chaillou, S.; Champomier-Vergès, M.C.; Cornet, M.; Crutz-Le Coq, A.M.; Dudez, A.M.; Martin, V.; Beaufi, S.; Darbon-Rongère, E.; Bossy, R.; Loux, R.; et al. The complete genome sequence of the meat-borne lactic acid bacterium Lactobacillus sakei 23K. Nat. Biotechnol. 2005, 23, 1527-1533. [CrossRef]

9. McLeod, A.; Zagorec, M.; Champomier-Vergès, M.C.; Naterstad, K.; Axelsson, L. Primary metabolism in Lactobacillus sakei food isolates by proteomic analysis. BMC Microbiol. 2010, 10, 120. [CrossRef]

10. McLeod, A.; Snipen, L.; Naterstad, K.; Axelsson, L. Global transcriptome response in Lactobacillus sakei during growth on ribose. BMC Microbiol. 2011, 11, 145. [CrossRef]

11. Fiehn, O. Metabolomics - the link between genotypes and phenotypes. Plant Mol. Biol. 2002, 48, $155-171$. [CrossRef]

12. Laghi, L.; Versari, A.; Marcolini, E.; Parpinello, G.P. Metabonomic investigation by ${ }^{1} \mathrm{H}-\mathrm{NMR}$ to discriminate between red wines from organic and biodynamic grapes. Food Nutr. Sci. 2014, 5, 52-59. [CrossRef]

13. Lauret, R.; Morel-Deville, F.; Berthier, F.; Champomier-Vergès, M.C.; Postma, P.; Ehrlich, S.D.; Zagorec, M. Carbohydrate utilization in Lactobacillus sake. Appl. Environ. Microbiol. 1996, 62, 1922-1927. [CrossRef]

14. Zwietering, M.H.; Jongenburger, I.; Rombouts, F.M.; van't Riet, K. Modeling of the bacterial growth curve. Appl. Environ. Microbiol. 1990, 56, 1875-1881. [CrossRef]

15. Arioli, S.; Montanari, C.; Magnani, M.; Tabanelli, G.; Patrignani, F.; Lanciotti, R.; Mora, D.; Gardini, F. Modelling of Listeria monocytogenes Scott A after a mild heat treatment in the presence of thymol and carvacrol: Effects on culturability and viability. J. Food Eng. 2019, 240, 73-82. [CrossRef]

16. Tabanelli, G.; Montanari, C.; Arioli, S.; Magnani, M.; Patrignani, F.; Lanciotti, R.; Mora, D.; Gardini, F. Physiological response of Saccharomyces cerevisiae to citral combined with thermal treatment. LWT Food Sci. Technol. 2019, 101, 827-834. [CrossRef]

17. Zhu, C.; Li, C.; Wang, Y.; Laghi, L. Characterization of yak common biofluids metabolome by means of proton nuclear magnetic resonance spectroscopy. Metabolites 2019, 9, 41. [CrossRef]

18. Fadda, S.; Anglade, P.; Baraige, F.; Zagorec, M.; Talon, R.; Vignolo, G.; Champomier-Vergès, M.C. Adaptive response of Lactobacillus sakei $23 \mathrm{~K}$ during growth in the presence of meat extracts: A proteomic approach. Int. J. Food Microbiol. 2010, 142, 36-43. [CrossRef]

19. Axelsson, L. Lactic acid bacteria: Classification and physiology. In Lactic Acid Bacteria: Microbiology and Functional Aspects, 3rd ed.; Salminen, S., von Wright, A., Ouwehand, A., Eds.; Marcel Dekker: New York, NY, USA, 2004; pp. 1-66, ISBN 0-8247-5332-1.

20. Rimaux, T.; Riviére, A.; Illeghems, K.; Weckx, S.; De Vuyst, L.; Leroy, F. Expression of the arginine deiminase pathway genes in Lactobacillus sakei is strain-dependent and is affected by environmental pH. Appl. Environ. Microbiol. 2012, 78, 4874-4883. [CrossRef]

21. Gänzle, M.G. Lactic metabolism revisited: Metabolism of lactic acid bacteria in food fermentations and food spoilage. Curr. Opin. Food Sci. 2015, 2, 106-117. [CrossRef]

22. Irmler, S.; Bavan, T.; Oberli, A.; Roetschi, A.; Badertscher, R.; Guggenbühl, B.; Berthoud, H. Catabolism of serine by Pediococcus acidilactici and Pediococcus pentosaceus. Appl. Environ. Microbiol. 2013, 79, 1309-1315. [CrossRef]

23. Skeie, S.; Kieronczyk, A.; Næss, R.M.; Østlie, H. Lactobacillus adjuncts in cheese: Their influence on the degradation of citrate and serine during ripening of a washed curd cheese. Int. Dairy J. 2008, 18, 158-168. [CrossRef]

24. Biagioli, M.; Laghi, L.; Carino, A.; Cipriani, S.; Distrutti, E.; Marchianò, S.; Parolin, C.; Scarpelli, P.; Vitali, B.; Fiorucci, S. Metabolic variability of a multispecies probiotic preparation impacts on the anti-inflammatory activity. Front. Pharmacol. 2017, 8, 505. [CrossRef]

25. Parolin, C.; Marangoni, A.; Laghi, L.; Foschi, C.; Ñahui Palomino, R.A.; Calonghi, N.; Cevenini, R.; Vitali, B. Isolation of vaginal Lactobacilli and characterization of anti-Candida activity. PLoS ONE 2015, 10, e0131220. [CrossRef] 
26. Picone, G.; Laghi, L.; Gardini, F.; Lanciotti, R.; Siroli, L.; Capozzi, F. Evaluation of the effect of carvacrol on the Escherichia coli 555 metabolome by using ${ }^{1} \mathrm{H}-\mathrm{NMR}$ spectroscopy. Food Chem. 2013, 141, 4367-4374. [CrossRef]

27. Liu, S.Q.; Holland, R.; McJarrow, P.; Crow, V.L. Serine metabolism in Lactobacillus plantarum. Int. J. Food Microbiol. 2003, 89, 265-273. [CrossRef]

(C) 2020 by the authors. Licensee MDPI, Basel, Switzerland. This article is an open access article distributed under the terms and conditions of the Creative Commons Attribution (CC BY) license (http://creativecommons.org/licenses/by/4.0/). 